\title{
Progestagen dynamics in preovulatory follicles of rats
}

\author{
Maria Szołtys \\ Department of Animal Physiology, Jagiellonian University, Cracow, Poland
}

\begin{abstract}
Summary. The levels of progestagens in isolated follicles of rats were low until 16.00 hours, increased to reach a maximum at $\mathbf{1 8 . 0 0}$ hours and then gradually declined up to the time of ovulation.
\end{abstract}

It is known that during pro-oestrus in the rat a peak of progesterone secretion appears after the LH surge (Schwartz, 1969; Schneider, Piascek \& Gay, 1970; Piascek, Schneider \& Gay, 1971). In previous experiments (Noworyta \& Szoltys, 1975), attempts were made to find the ovarian tissue from which this secretion was derived, and histochemical investigation of $3 \beta$-hydroxysteroid dehydrogenase ( $3 \beta-H S D)$ suggested that granulosa cells were responsible. In the present experiment, preovulatory follicles were isolated at various times on the day of pro-oestrus up to the moment of ovulation to determine whether the activity of $3 \beta$-HSD correlates with progestagen synthesis.

Mature female Wistar rats were kept in a $12 \mathrm{hr}$ light $/ 12 \mathrm{hr}$ dark schedule, and those animals which had had at least 3 consecutive, regular 4-day cycles were chosen for investigation.

All animals ovulated between 02.00 and 04.00 hours. Animals were killed on the day of prooestrus at $08.00,11.00$ and 14.00 hours and then every $2 \mathrm{hr}$ until the time of ovulation. After excision, the ovaries were placed into Ringer's solution and preovulatory follicles were isolated under the dissecting microscope. Follicles were weighed, immediately frozen and stored at $-20^{\circ} \mathrm{C}$ until they were analysed. For steroid analysis, the follicles were homogenized in $0.5 \mathrm{ml}$ phosphate buffer and 50-100 $\mu \mathrm{l}$ aliquots of homogenate were extracted with petroleum ether. The amount of progestagen was determined by means of a competitive protein-binding assay (Murphy, 1967; Johansson, Neill \& Knobil, 1968). Dog plasma was diluted to $0 \cdot 8 \%$ and $\left[1,2-{ }^{3} \mathrm{H}\right]$ corticosterone (sp. act. 40 $\mathrm{Ci} / \mathrm{mmol}$, New England Nuclear) was used as labelled ligand. The relative binding of 14 different steroids was $<0.1 \%$, except for $17 \alpha$-hydroxyprogesterone (100\% cross-reaction) and $20 \alpha$-hydroxypregn-4-en-3-one ( $6 \%$ cross-reaction), and the estimated progestagen therefore contained these two steroids as well as progesterone. The recovery of progesterone ranged from $76-100 \%$ and the lower limit of sensitivity of the assays was of the order of $0.5 \mathrm{ng}$.

The results, showing peak progestagen concentrations at 18.00 hours, are given in Table 1 .

Table 1. Dynamics of progestagen concentration in preovulatory follicles of rats

\begin{tabular}{|c|c|c|c|c|}
\hline \multirow[b]{2}{*}{$\begin{array}{l}\text { Pro-oestrus } \\
\text { (hours) }\end{array}$} & \multirow[b]{2}{*}{$\begin{array}{l}\text { No. of } \\
\text { animals }\end{array}$} & \multirow[b]{2}{*}{$\begin{array}{l}\text { No. of } \\
\text { isolated } \\
\text { follicles }\end{array}$} & \multicolumn{2}{|c|}{$\begin{array}{l}\text { Progestagen conc. } \\
\text { (mean } \pm \text { S.E.M. }\end{array}$} \\
\hline & & & $\begin{array}{l}\mathrm{ng} / \mathrm{mg} \\
\text { follicular } \\
\text { tissue }\end{array}$ & $\mathrm{ng} /$ follicle \\
\hline 08.00 & 4 & 25 & $3 \cdot 1 \pm 1 \cdot 6$ & $1.1 \pm 0.6$ \\
\hline 11.00 & 4 & 17 & $5 \cdot 7 \pm 1.8$ & $2 \cdot 3 \pm 0.7$ \\
\hline 14.00 & 4 & 19 & $2 \cdot 5 \pm 1.2$ & $1.3 \pm 0.6$ \\
\hline 16.00 & 4 & 20 & $5 \cdot 1 \pm 1 \cdot 5$ & $2.7 \pm 0.8$ \\
\hline 18.00 & 4 & 29 & $26.7 \pm 7 \cdot 5$ & $16 \cdot 2 \pm 5 \cdot 1$ \\
\hline 20.00 & 4 & 24 & $11 \cdot 1 \pm 0.8$ & $8 \cdot 1 \pm 1 \cdot 3$ \\
\hline 22.00 & 5 & 25 & $9.9 \pm 2.8$ & $5.9 \pm 1.5$ \\
\hline 24.00 & 4 & 19 & $8 \cdot 6 \pm 1.4$ & $4.8 \pm 0.8$ \\
\hline 02.00 & 4 & 24 & $6.7 \pm 2.2$ & $4 \cdot 7 \pm 1 \cdot 6$ \\
\hline
\end{tabular}


The concentration of progesterone in rat ovarian venous plasma during pro-oestrus has been extensively investigated (Hashimoto, Henricks, Anderson \& Melampy, 1968; McDonald, Seiki, Prizant \& Goldfien, 1969; Schneider et al., 1970; Feder, Brown-Grant \& Corker, 1971; Piascek et al., 1971). In all these experiments, an afternoon increase in progesterone concentration was shown, but there is no agreement concerning the time at which this increase begins. Feder et al. (1971) found that progesterone increased at 15.00 hours, Piascek et al. (1971) between 16.30 and 18.30 hours, McDonald et al. (1969) between 18.00 and 20.00 hours, and Schneider et al. (1970) in one group of animals at $\mathbf{1 4 . 0 0}$ hours, and in another group at $\mathbf{1 7 . 0 0}$ hours. Furthermore, the time at which the peak value is reached for progesterone in ovarian venous plasma is also in dispute. Some authors (McDonald et al., 1969; Schneider et al., 1970; Piascek et al., 1971; Feder et al., 1971) found high plasma levels of progesterone at $18.00,20.00,21.00$ and 24.00 hours, but did not continue the experiments longer than this. Lindner \& Zmigrod (1967) studied ovarian homogenates at 6-hr intervals and found the highest level of progesterone at 15.00 hours (pro-oestrus), followed by a lower value at 21.00 hours (oestrus). Generally, preovulatory progesterone began to increase in the afternoon of pro-oestrus and reached its maximum several hours later. None of these experiments showed which ovarian tissue produced the preovulatory progesterone.

Comparing the results reported here with those published previously, a distinct coincidence in the content of progesterone in ovarian venous plasma and progestagen in isolated preovulatory pro-oestrous follicles is shown. In the morning and early afternoon, the concentration of progestagen was low in all material examined. By 18.00 hours, the level of follicular progestagen had increased to a maximum. After this time, the amount of progestagen gradually decreased, probably due to the release of hormone into the blood. The peak of progesterone in follicular fluid immediately follows the maximum activity of $3 \beta$-HSD in granulosa cells which has been shown to be 14.00 hours (Noworyta \& Szołtys, 1975).

From these results, it can be concluded that the preovulatory surge of LH activates $3 \beta-\mathrm{HSD}$ in follicular granulosa cells. Consequently, increased synthesis of progestagen occurs to give a maximum follicular concentration at 18.00 hours, i.e. about $4 \mathrm{hr}$ after the maximum activity of $3 \beta$-HSD. Progestagens are then released from the follicles into the circulation.

This investigation was supported by NIH PL 480 Research Agreement No. 05-001-0 Annex 05-040-N. I thank Doc. Dr S. Stoklosowa, Professor Dr A. Kulczycki, Doc. Dr R. Rembiesa, Doc. Dr T. Radecki and Dr B. Cook for their help during this study.

\section{References}

Feder, H.H., Brown-Grant, K. \& Corker, C.S. (1971) Pre-ovulatory progesterone, the adrenal cortex and the "critical period" for luteinizing hormone release in rats. $J$. Endocr. 50, 29-39.

Hashimoto, I., Henricks, D.M., Anderson, L.L. \& Melampy, R. (1968) Progesterone and pregn-4en-20 $\alpha$-ol-3-one in ovarian venous blood during various reproductive states in the rat. Endocrinology 82, 333-34!.

Johansson, E.D.B., Neill, J.D. \& Knobil, E. (1968) Periovulatory progesterone concentration in the peripheral plasma of the rhesus monkey with a methodologic note on the detection of ovulation. Endocrinology 82, 143-148.

LINDNER, H.R. \& ZMIGROD, A. (1967) Microdetermination of progestins in rat ovaries: progesterone and 20a-hydroxypregn-4-en-3-one content during pro-oestrus, oestrus and pseudopregnancy. Acta endocr., Copenh. 56, 16-26.

McDonald, D.M., Seiki, K., Prizant, M. \& Goldfien, A. (1969) Ovarian secretion of progesterone in relation to the Golgi apparatus in lutein cells during estrus of the rat. Endocrinology 85, 236-243.
Murphy, B.E.P. (1967) Some studies of the proteinbinding of steroids and their application to the routine micro and ultra-micromeasurements of various steroids in body fluids by competitive protein-binding radioassay. J. clin. Endocr. Metab. 27, 973-990.

Noworyta, B. \& Szoltys, M. (1975) Dynamics of the $\Delta^{5}-3 \beta$-hydroxysteroid dehydrogenase activity in rat follicular granulosa cells during proestrus. Bull. Acad. pol. Sci. Cl. II Sér. Sci. biol. 23, 65-69.

Piascek, B.E., Schneider, T.C. \& Gay, V.L. (1971) Sequential study of luteinizing hormone (LH) and "progestin" secretion on the afternoon of proestrus in the rat. Endocrinology 89, 39-45.

Schneider, T., Piascek, B. \& Gay, V. (1970) Simultaneous measurements of progesterone and $20 \alpha-\mathrm{OH}$ pregn-4-en-3-one in ovarian venous blood on the afternoon of proestrus in the rat. Fedn Proc. Fedn Am. Socs exp. Biol. 29, 440.

Schwartz, N.B. (1969) A model for regulation of ovulation in the rat. Recent Prog. Horm. Res. 25, 1-55. 